\title{
New evidences for core processing of non-flint, lithic materials in the Late Palaeolithic and Mesolithic of Poland
}

\author{
Grzegorz Osipowicz ${ }^{1}$ and Iwona Sobkowiak-Tabaka ${ }^{2}$
}

1. Institute of Archaeology, Nicolaus Copernicus University, ul Szosa Bydgoska 44/48, 87-100 Torun, Poland. Email: grezegor@umk.pl

2. Institute of Archaeology and Ethnology, Polish Academy of Sciences, Centre for Prehistory and Medieval Studies, ul. Rubież 46, 61-612 Poznań, Poland. Email: iwona.sobkowiak@iaepan.poznan.pl

\begin{abstract}
:
In the Late Palaeolithic and Mesolithic core processing in Poland was dominated by flint raw materials. The present paper considers the occurrence of non-flint assemblages at the sites Lubrza and Ludowice (Polish Lowland). The focus is on recognition of petrographic studies, technology, typology and use-wear of inventories from both sites. The collections contain debitage, cores and different kinds of tools. As a result the identification of granite, sandstone, quartzite, gneisses, mudstones, slates and single minerals of quartzes and feldspars was established. The use-wear analysis brought good results only in case in porphyry artefacts. The described analyses are accompanied by a review of European non-flint assemblages from Late Palaeolithic and Mesolithic sites and discussion of the role of this type of raw material in core processing.
\end{abstract}

Keywords: Poland; Late Palaeolithic; Mesolithic; quartz porphyry; fine crystalline sandstone; quartzite; granite

\section{Introduction}

Stone products constitute one of the basic sources of information identified at Stone Age sites. In case of the earlier and middle phases of this period it is often the only source. The area of present day Poland is rich in flint, which made it the basic raw material used for tool production in this region during prehistoric times. Other rock types had less importance in this regard, although it is commonly accepted that they were used for making macrolithic forms of different types. However, despite the fact that this is often reflected at archaeological sites, the introduction of such a classification, and particularly its uncritical acceptance, may lead to mistakes, It is no secret that in areas of difficult access to flint, technically inferior types of fine crystalline rocks, e.g. quartz, quartzite, fine crystalline sandstones etc., were often utilized as equivalents in the production of tools for everyday use. One cannot exclude that this happened also within the territory of modern-day Poland. Recently, a very interesting collection of non-flint artefacts was discovered during the study of multicultural sites of Lubrza 10 (Lubrza commune) and Ludowice 6 (Wąbrzeźno commune).

Published by the School of History, Classics and Archaeology, University of Edinburgh ISSN: 2055-0472. URL: http://journals.ed.ac.uk/lithicstudies/

This work is licensed under a Creative Commons Attribution 2.5 UK: Scotland License. 


\section{Localisation of the sites}

The concentration of Late Palaeolithic sites in the area of Lubrza (Lubuskie Lake District, western Poland - Figure 1 - map of Poland) was registered during rescue excavations (Kabaciński \& Sobkowiak-Tabaka 2011a, 2011 b) and in the course of a research project which has been conducted since 2010. The sites are located in the young moraine landscape characterised by a large number of moraine hills; glacial troughs carried melted waters of the last glacier during the Late Glacial period and buried dead-ice supplied newly emerged lakes with water.

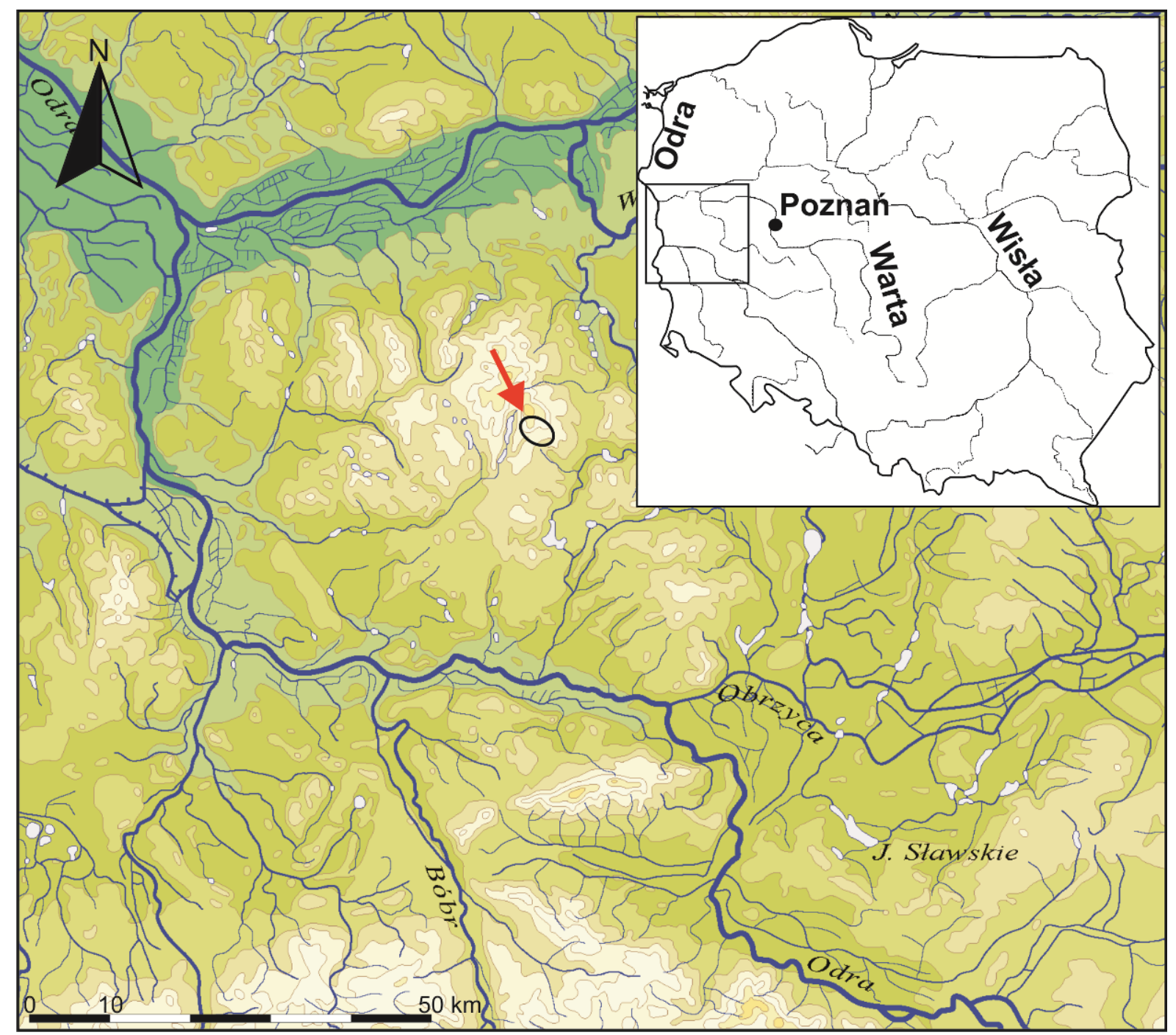

Figure 1. Concentration of the Late Palaeolithic and Mesolithic sites in Lubrza (black ellipse).

Several Late Palaeolithic sites were registered on very steep shores of a deep lake that originated from the melting block of dead-ice. Settlement remains of Federmesser societies have been recorded at two sites so far (Lubrza, sites 10 and 42). Several hundred years later Świderian societies occupied at least three camps on the shores of the lake (site 11, 37, 42 and perhaps 10). Remains of Mesolithic hunters-gatherer occupation have also been recognised at the site (Kabaciński \& Sobkowiak-Tabaka 2011a, b; Okuniewska-Nowaczyk \& SobkowiakTabaka 2014). 
The Ludowice 6 site is located in the central part of the Chełmno Lake District, on the Chełmińska Height (central Poland), in the contact zone of sander and a large kettle hole, filled with biogenic sediments (peat) (Figure 2). Archaeological research took place here in the years 2009-2013 over an area of $756 \mathrm{~m}^{2}$. The group of collected artefacts includes: 13,595 items made of flint (365 from the Late Palaeolithic and the rest from the Mesolithic), 733 artefacts of other stone materials, 227 bones and (in the peat) a few wooden artefacts. The main settlement phase at the site took place in the Late Mesolithic, when it was frequently visited by representatives of late Komornica culture (post Maglemose tradition).
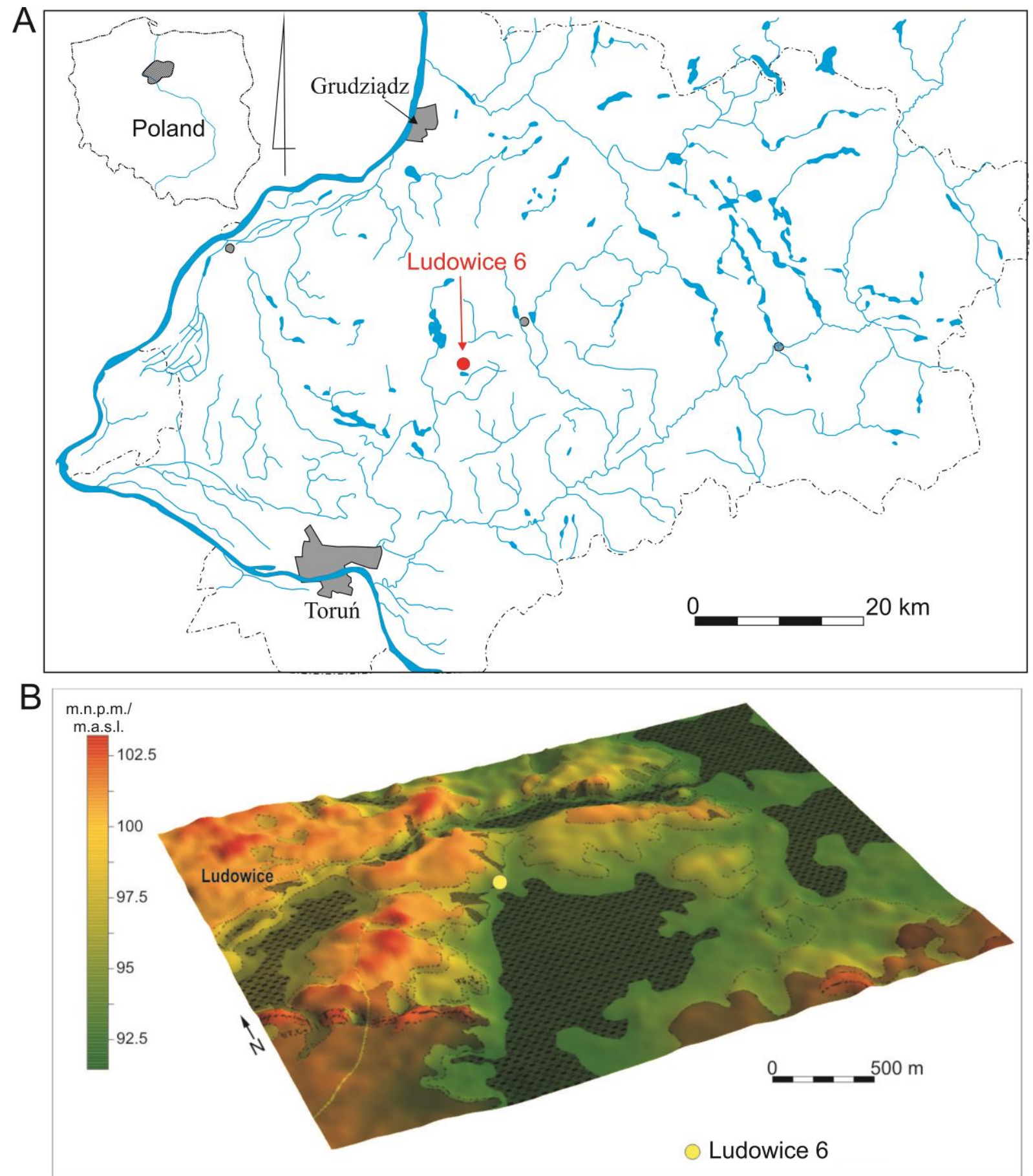

Figure 2. Localisation of the Ludowice 6 Mesolithic site. 


\section{Materials, methods and results regarding non-flint lithic artefacts}

Two seasons of excavations at Late Palaeolithic site no. 10 in Lubrza produced approx. 1,600 artefacts made of Cretaceous erratic flint. Noteworthy are 56 pieces made of finecrystalline quartzite (Figure 3), fairly uniform in colour, e.g. pale brown on the surface and pale brown-grey on the fresh fractures (10YR 7-6/3-4 and 2,5Y 7-6/2 according to the Munsell Soil Color Chart), and with matt gloss and semi-gloss on the surface. Quartzite fracture is mainly irregular but slightly conchoidal.

The technical parameters of quartzite from the Lubrza site determining its suitability for exploitation, i.e. cleavage and hardness, do not differ from good quality flint. The quartzite has a very fine crystalline disordered texture which significantly reduced the probability of obtaining an inappropriate surface during processing. The presence of small grains of quartz could result in very thin edges of the analysed artefacts (Mrozek-Wysocka 2013).

The quartzite inventory from Lubrza contains mainly flakes (one cortical flake, 25 flakes from single platform cores and two from opposite platform cores), blades (13 blades from single platform cores) and debris (15 pieces) (Figure 4). The average length of flake varies between 19-56 mm, their width ranges from 19 to $52 \mathrm{~mm}$ and their thickness falls between 3$13 \mathrm{~mm}$. The average length of blades is $29-50 \mathrm{~mm}$. The artefacts were mostly concentrated within 3 square meters of trench IV, while only single pieces were registered outside the concentration. Refitting analysis still needs to be undertaken in order to determine whether the pieces are from the same nodule. The technique of Soft Hammerstone Percussion was employed, as evidenced by the features their bulbs (Pelegrin 2000). All identified butts are smooth.

Unlike the inventory from Ludowice, the quartzite assemblage from Lubrza has not produced any use-wear traces thus far. The edges of artefacts are well preserved and display no traces of mechanical damage ${ }^{1}$.

The most difficult issue to be addressed is the provenience of the quartzite. None of the known outcrops in Poland is comparable with the petrographic character of the analysed artefacts. The fine quality of quartzite from Lubrza suggests its provenience from primary contexts / outcrops (Mrozek-Wysocka 2013). The most important quartzite outcrops in Poland are located in Lower Silesia, in the area of Holy Cross Mts. and in the south of Great Poland (Bolewski et al. 1991:123). At the current stage of research, the question of the place of origin of quartzite remains unanswered.

During the excavations at Ludowice 6, 579 stone artefacts made of non-flint raw materials have been discovered and identified as the result of potential core exploitation ${ }^{2}$. Their distribution, as well as morphological features allowed to suggest connection with the Mesolithic (Osipowicz in press). Petrographic study of this collection showed that the majority of them were made from red quartz porphyry, ferruginous quartz sandstone or finegrained red granite. The collection contained also (in much smaller amounts) items of other types of granite and sandstone, quartzites, gneisses, mudstones, slates and single minerals of quartzes and feldspars. Most of the artefacts were discovered in five concentrations (Osipowicz in press). 

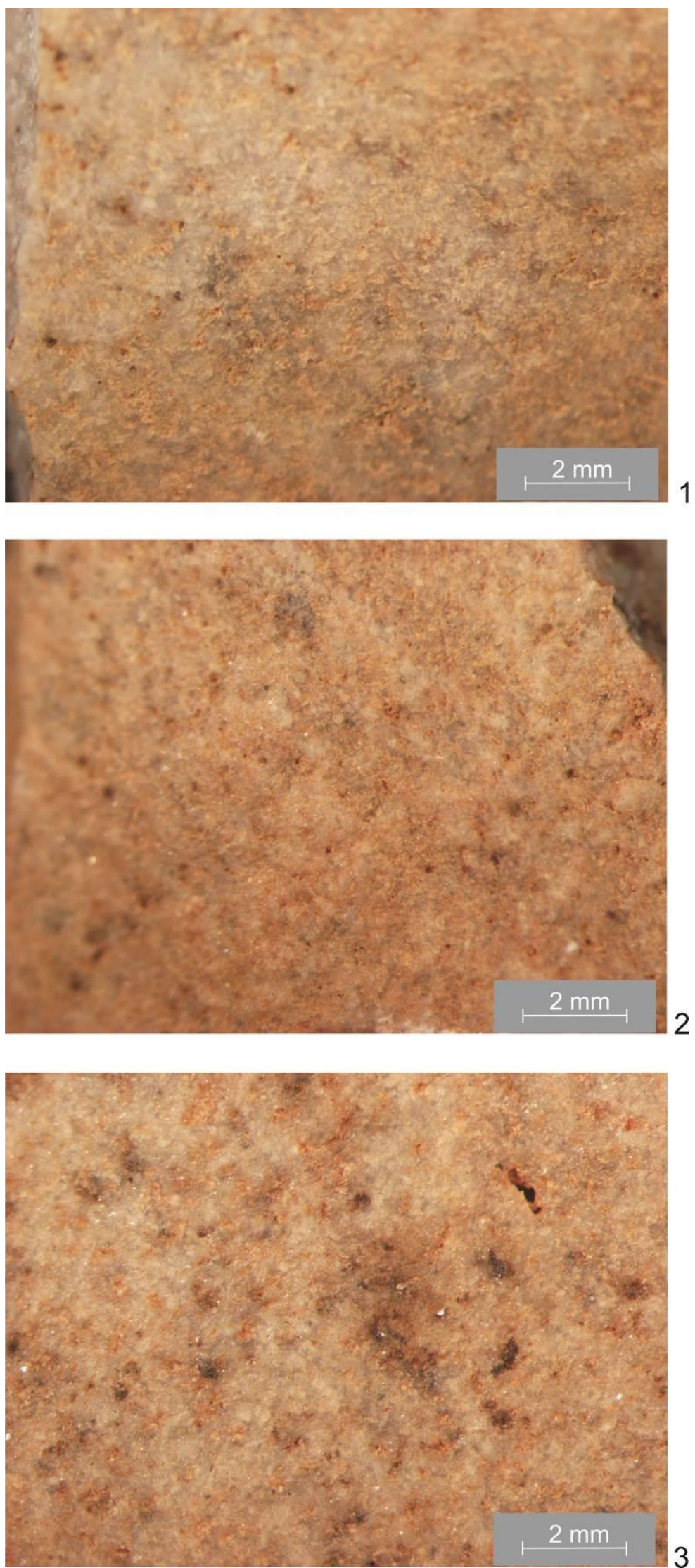

Figure 3. Image of a spatial sample viewed under stereoscopic microscope, magnification from stereoscopic microscope, magnification 10x. 1. sample no. 133; 2. sample no. 179; 3. sample no. 184 (photo by M. WysockaMrozek). 


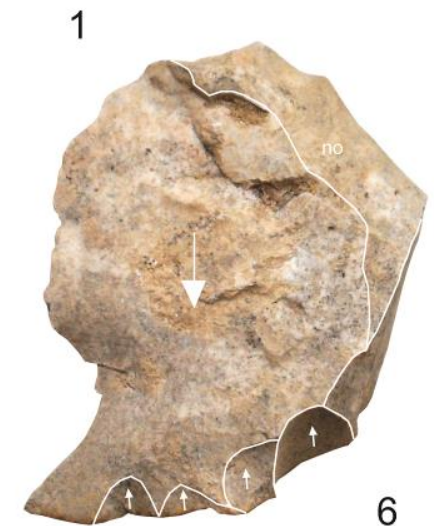

5
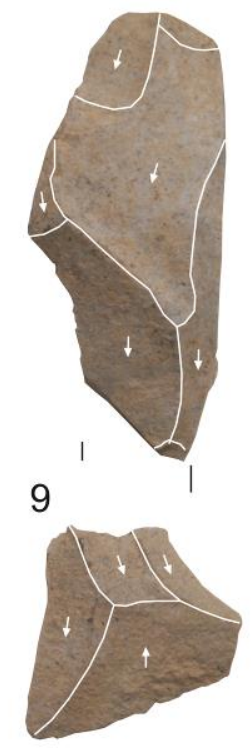

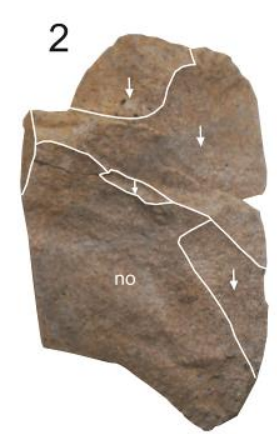

6

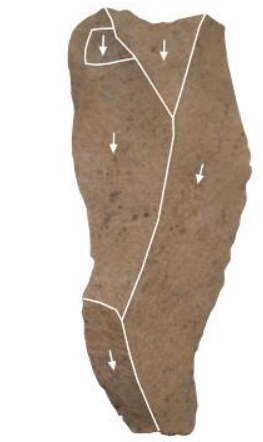

7

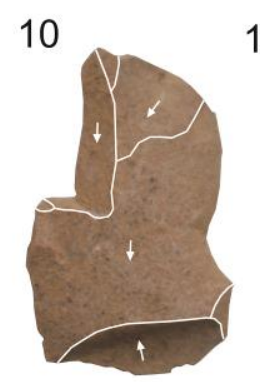

11
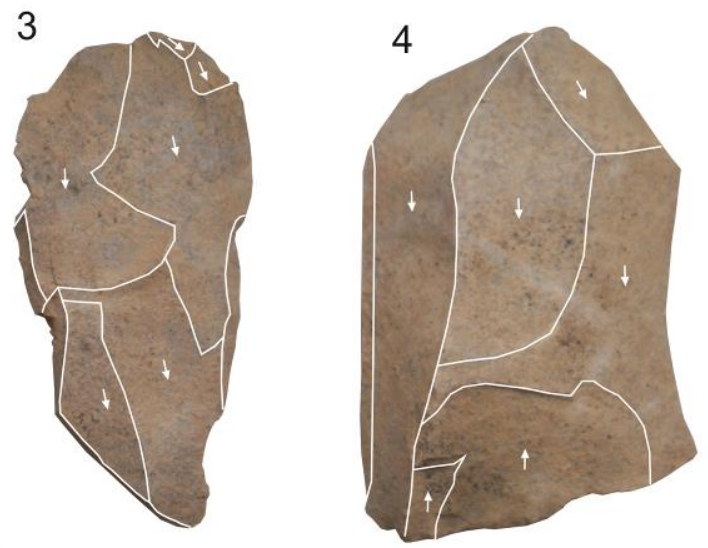

8

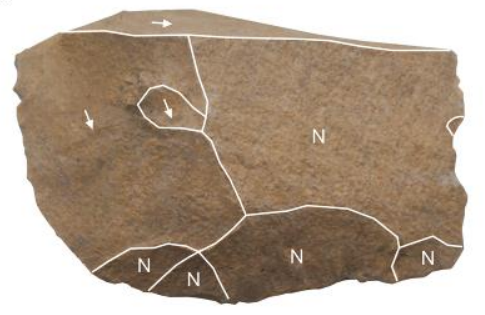

12

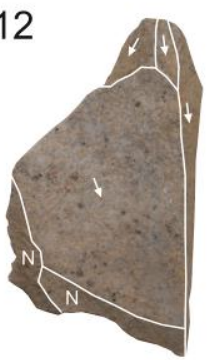

13
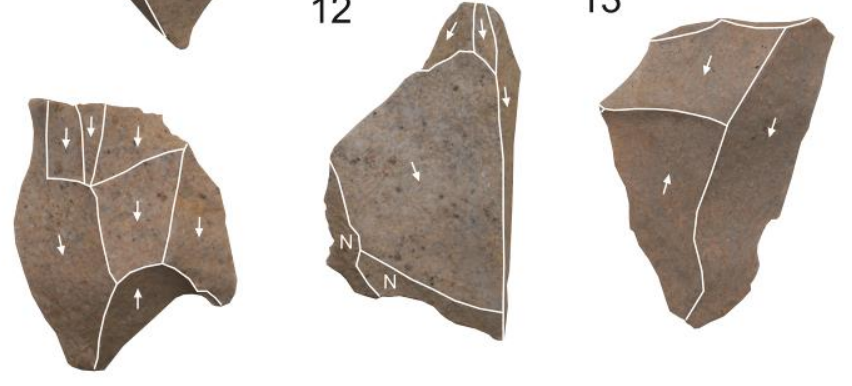

$5 \mathrm{~cm}$

Figure 4. Quartzite artefacts from Lubrza, site 10 (photo by. A. Tabaka).

Red quartz porphyry was the most frequently represented type of raw material in the collection. 297 artefacts made of this raw material were discovered. The group includes (Figure 5: 1-10): 13 cores (a single platform blade core, two with changed orientation or opposed platforms, three splintered, three multiple platforms flake cores and four forms with single negatives), 15 blades, 247 flakes and pieces of porphyry waste, 13 technical specimens and 22 morphological tools (four end-scrapers, retouched blade, fragment of a microlith certainly a triangle, two side scrapers, four retouched flakes, retouched core form, five burins and four forms the features of which do not allow for their more certain classification).

Use-wear analysis was possible only for the porphyry collection. Initially part of this was conducted with a Nikon SMZ-2T microscopic-computer kit. This device enables the limiting magnitude up to 12.6x (with real magnitude 120x), computer digitization and processing of optical images. During further polish analysis a Zeiss-Axiotech microscopic-computer kit was used, which enables the limiting magnitude up to 50x (with real magnitude 500x). Photos 6a $\& 6 \mathrm{~d}$ were made with the Nikon SMZ-2T, $6 \mathrm{~b} \& 6 \mathrm{c}$ with the Zeiss-Axiotech. 

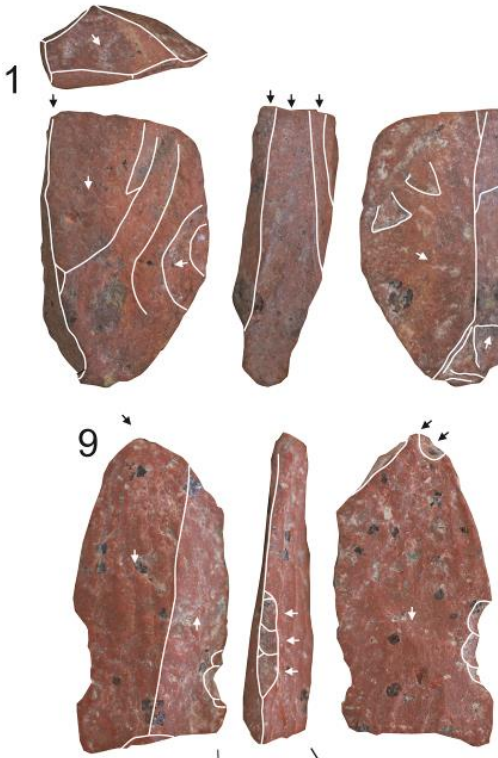

13

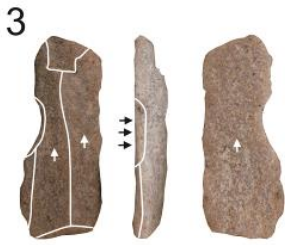

14

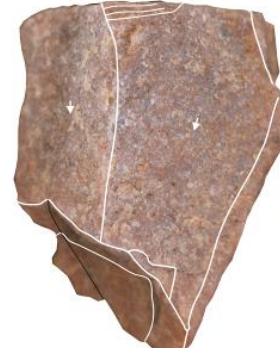

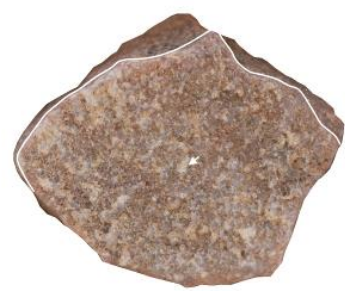

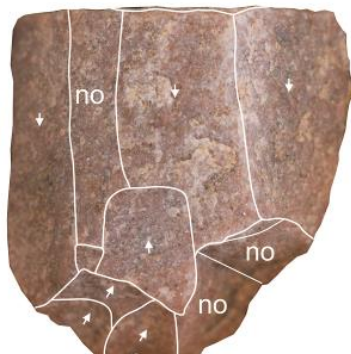

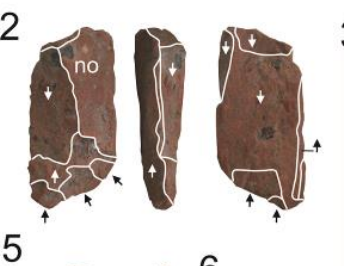
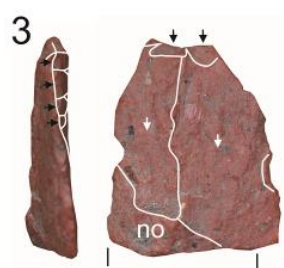

5
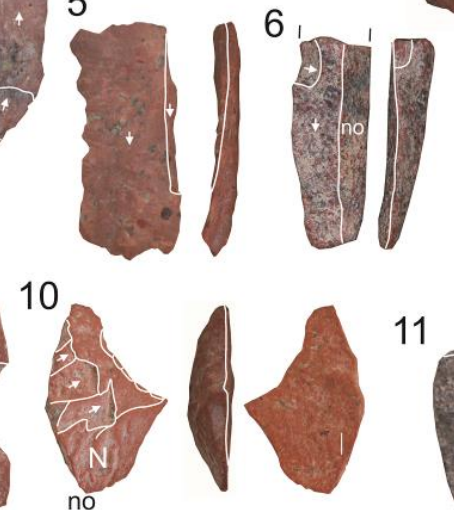

11
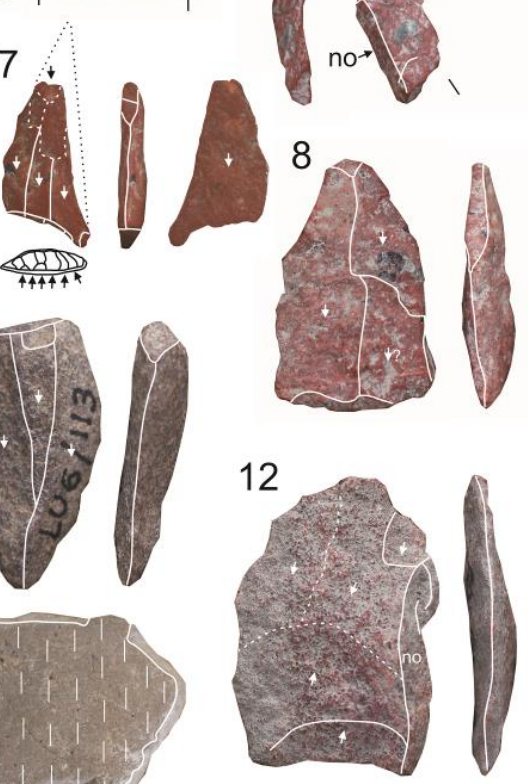

15
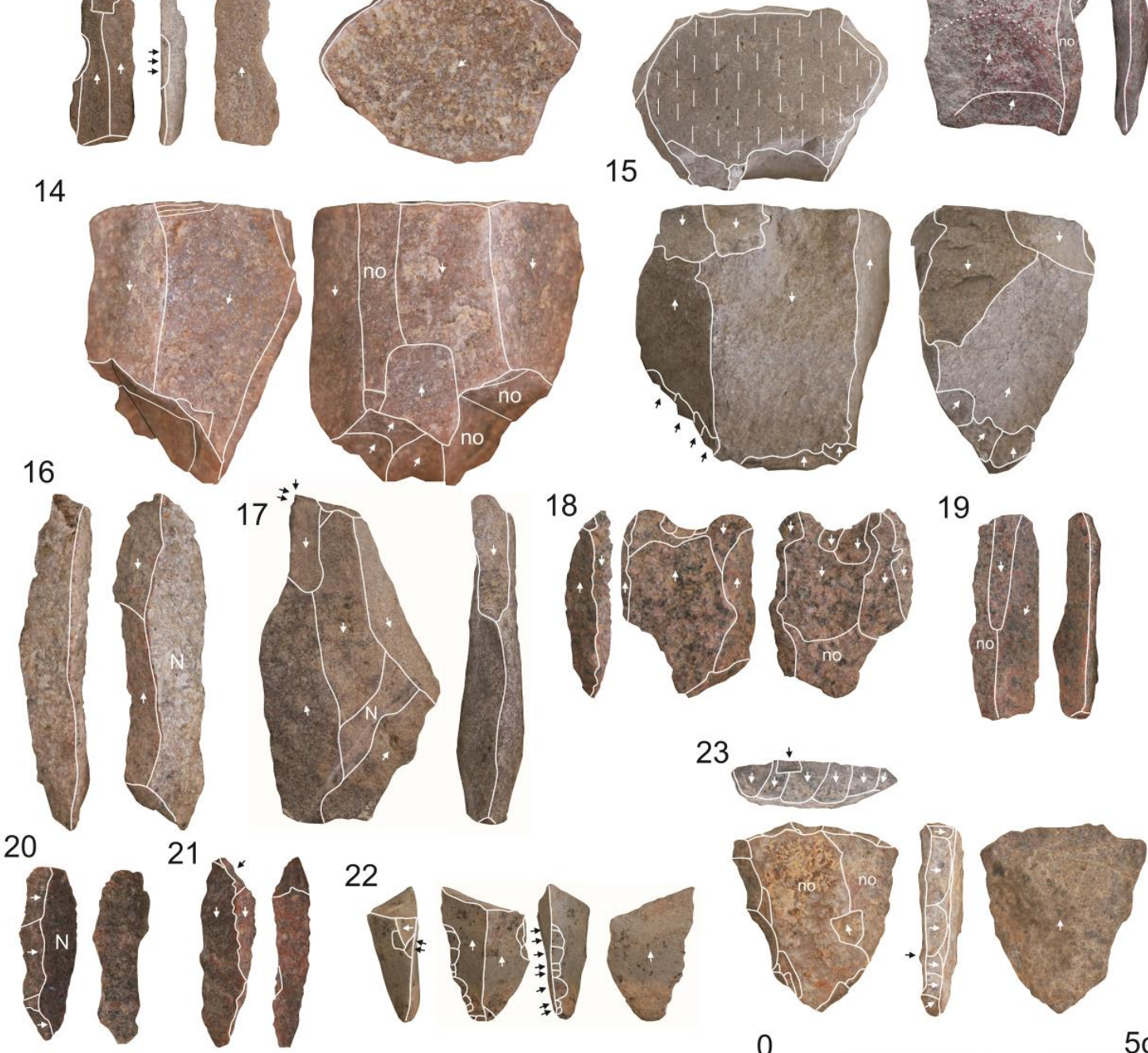

$$
0
$$

$5 \mathrm{~cm}$

Figure 5. Stone artefacts from the Ludowice 6 site: quartz porphyry (1-10), quartzite sandstone (11-17), granite (18-21), quartzite (22-23). 
Use-wear analysis of the porphyry collection led to recognition of very uniform damage. All the analyzed artefacts have rounded edges, which indicate significant post-depositional changes of their surface. However, the collection contained two specimens with damage of very probable usage character. On the first one (flake) rounding was observed, very clearly visible also macroscopically (Figure 6a), and the further microscopic analysis of which showed the presence of diffuse linear polish with an invasive degree of intrusion covering the top parts of the micro structure of the material (Figure 6b). On the second artefact (endscraper) were observed both very well developed polish as well as linear traces (Figure 6c). The only microlith in the collection was also subjected to use-wear analysis. The specimen showed a "spin off” and a series of several micro-burin scars, completely damaging the point of the artefact at one of its sides (Figure 6d). Observed traces indicate that the specimen was used as an arrowhead.
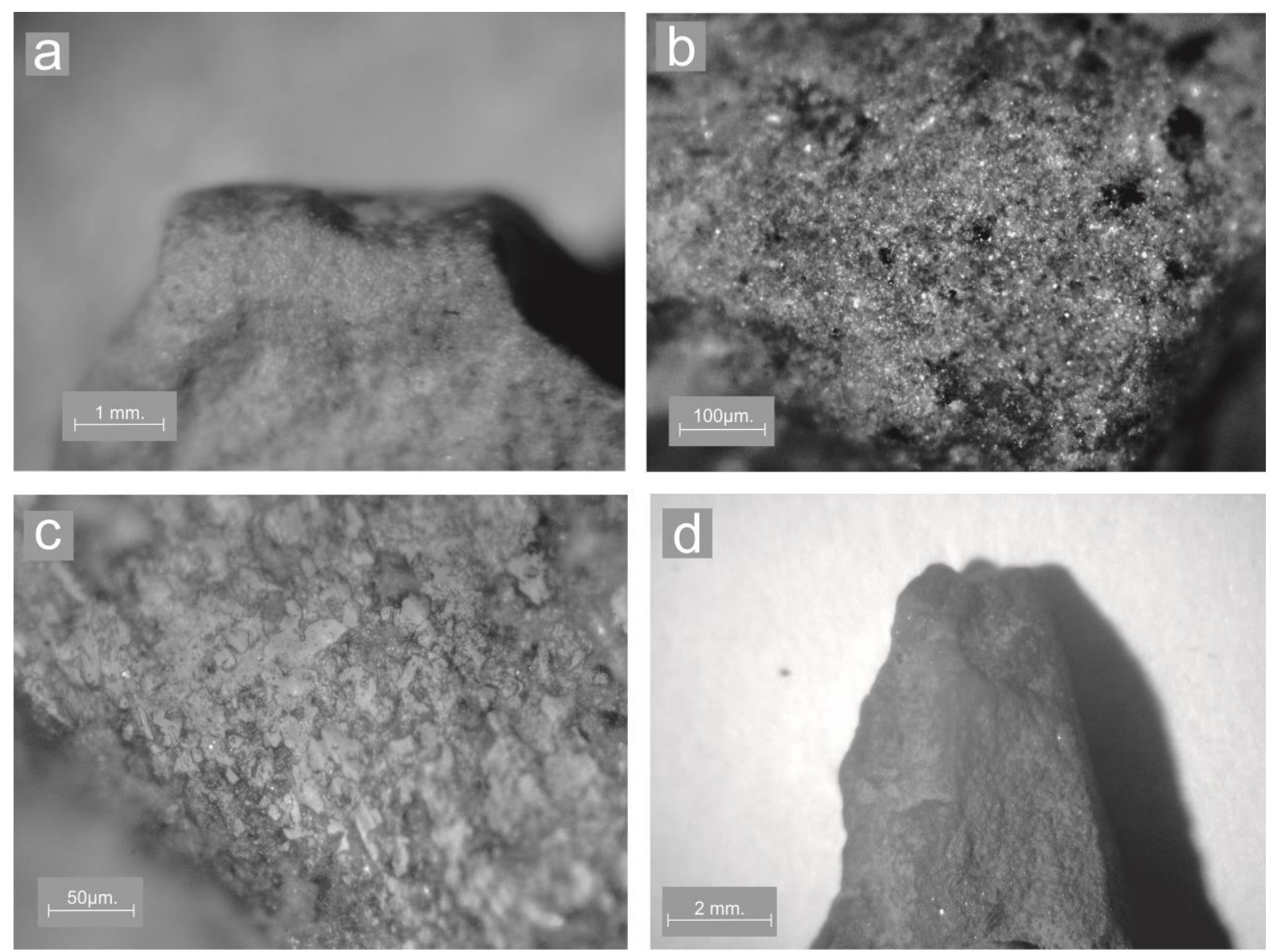

Figure 6. The example of probable use-wear traces observed on stone (non-flint) artefacts from Ludowice 6.

The collection from Ludowice contained 99 artefacts of red quartzite sandstone. Distinguished were: six cores (four single platform cores and one opposed platform core), 13 blades, two blade technical forms, 74 flakes and pieces of waste and seven artefacts considered as morphological tools (six burins and a retouched blade) (Figure 5: 11-17). Moreover, 28 artefacts made of grey quartz sandstone were collected. The group of cores contained four single platform forms and a blade core specimen with the attributes of opposed platforms. The group of semi-products included one blade and 22 flakes and pieces of waste. The only distinguished morphological tool is a blade with a retouched notch.

115 artefacts made of red granite were distinguished, among which were found (Figure 5: 18-21): three core forms (unipolar flake core, bipolar splintered core and multi-striking 
platform flake core), 12 artefacts of blade parameters, four blade technical forms, 97 flakes and wastes and three forms with features of morphological tools (all of them are burins). The collection contained also 18 quartzite artefacts (Figure 5: 22-23): hypothetical core, four blades, 10 flakes and three tools (end-scraper, retouched blade, burin).

\section{Discussion}

The industries of non-flint rocks described in this article certainly contribute new knowledge about the Late Palaeolithic and Mesolithic of Poland (especially in the Polish Lowland). Only a few sites of this region have this type of artefacts in the inventories. Quartzite artefacts are known from Polish Magdalenian sites, e.g. Dzierżysław, Wilczyce, Klementowice (south-eastern Poland) and have sporadically been found at Świderian sites, e.g. Czerniejowice. There is some evidence that quartzite recorded in Wilczyce could have been procured from local outcrops (Sulgostowska 2005: 34). Several artefacts made of quartz have been registered lately at the Hamburgian site in Myszęcin (western Poland) (Kabaciński \& Sobkowiak-Tabaka 2013:156). A similar situation can be observed in the Mesolithic of Poland. The possibility of treatment of different kinds of non-flint rocks at early Holocene sites was first put forward by Krukowski \& Nowakowski (Nowakowski 1976: 68). Więckowska \& Chmielewska (2007: 30-33) have written recently about early Holocene artefacts of this type. One should also mention that artefacts made of red quartzite sandstone, analogous to those excavated in Ludowice, occurred in a relatively large numbers at the Mesolithic cemetery in Mszano (site 14) located only several tens of kilometres from Ludowice (personal communications with the site supervisor Marian Marcinak). Identified here as well, although less numerous, were artefacts made of red porphyry quartzite. These are probably all (or all those known) of the collections of this type of artefact found in Poland. Such aggregations are, however, present in European Prehistory, especially in places poor in high quality flint raw materials.

In areas devoid of good quality raw material e.g. in Finland, Late Palaeolithic societies utilised local quartzite and jasperoids, interpreted as metasomatic Precambrian rock which is characterized by relict cleavage directions of carbonate minerals (Kinkunen et al 1985:24-25). Quartzite outcrops are to be found also in the Czech Republic (Přichystal 2002), southern Germany, and in the region of Volhynia (Ukraine) (Sulgostowska 2005: 49). In the Central Rhineland Allerød assemblages are made mostly of local (regionally available) raw materials, such as Tertiary quartzite ${ }^{3}$ and siliceous slate (Kieselschifer or lydite ${ }^{4}$ ). It is worth mentioning that Late Glacial communities used also chalcedony ${ }^{5}$ and several types of Cretaceous flints, located 40-100 km far from this area (Baales 2001).

A similar situation can be found in the Mesolithic. Quartz and quartzite belonged to the basic materials used in tool production in some regions of Scandinavia and Ireland (Larsson 1990: 282; Price 1991: 220; Bang-Andersen 1996: 439; Bergman et al. 2003: 1456; Olofsson 2003: 3-4; Driscoll \& Warren 2007; Ballin 2009: 8-14; Bjartmann Bjerck 2008: 81; Hertell \& Tallavaara 2011: 11; Manninen \& Knutsson 2011: 169-173; Manninen \& Tallavaara 2011: 194). They occur also, for instance, in materials from the area of the Czech Republic, Estonia, Germany, Belgium, Netherlands, and even Spain (Gob \& Jacques 1985: 167; Pallarés \& Mora 1995: 68; Kriiska \& Lõugas 1999; Kind 2006: 217; Svoboda 2008: 229). At the Mesolithic Scandinavian sites one can find also porphyry artefacts (Larsson 1990: 282; Olofsson 2003: 3-4), constituting in some cases (e.g. the Garaselet site in Sweden) almost 3/4 of the collection (Olofsson 2003: 9). As (probably) at the Ludowice site, this rock was used in this region also for the production of microliths (Manninen \& Knutsson 2011: 146, 169, fig. 2). 
Quartzite sandstones were used in the Mesolithic at some Finnish and Estonian sites Kriiska (Kriiska \& Lõugas 1999; Kankaanpää \& Rankama 2011: 43). They were, however, also used in other region of Europe, e.g. in Spain (Pallarés \& Mora 1995: 68).

Granitoids were used in the Middle Stone Age mainly for production of macrolithic tools. The remains of granite working were found for instance in the Netherlands, Denmark and northern part of Urals (Holst 2010: 2873; Mosin \& Nikolsky 2010: 6).

\section{Conclusions}

In view of the small number of artefacts of quartzite registered at the site of Lubrza thus far, this raw material does not seem to have played any major technological role in the society that lived at the site. In light of the absence of any quartzite outcrops in this region and given the excellent quality of quartzite which suggests a primary context of its origin, it seems highly probable that the Late Palaeolithic group from Lubrza employed a very limited quantity of this raw material (perhaps 1- or 2 nodules), acquired as a result of exchange.

In the context of the widespread use of Baltic flint, particularly evident in the inventories from the Polish Lowland, preliminary results of quartzite utilisation by Late Palaeolithic communities in Lubrza could provide a valuable contribution to the study of long-distance contacts at the time.

A different situation can be recognised at the Ludowice 6 Mesolithic site. All the nonflint raw materials that were subjected here to core exploitation are of erratic origin. They were probably collected in the immediately surrounding area of the site. The most problematic question is the reason of knapping. The actual genesis of the collection of porphyry artefacts seems to be described by results of the morphological and use-wear analysis conducted. They show that porphyry knapping at Ludowice bears the characteristics of exploitation oriented at the production of blanks and tools used for various works. However, at this stage of research it is difficult to tell of what kind. The experimental studies conducted suggest that porphyry products are inferior to flint tools only to a slight degree (if at all), concerning both the effectiveness and resistance to damage, or versatility. Use-wear analysis of the experimental tools showed that use traces occurring on porphyry tools may be quite similar to those observed on flint specimens. However, it is premature to transfer these observations onto prehistoric artefacts.

It is even more difficult to talk about the reasons for granite knapping at the Ludowice site. Most likely, however, micro-debitage (wastes) and some of the flakes found there originate from the use of grinders and other macrolithic tools, the remaining ones showing small-scale core exploitation. Reasons for this remain unclear at this stage. An analogous situation is probably shown by artefacts made of quartzite sandstones. Some of the flakes are certainly a remnant of the process of production of grinding slabs. However, as can be inferred from the presence and forms of the excavated cores, parameters of the blades and flakes and, particularly, finds of specimens subjected to secondary treatment (e.g. morphological tools), the great majority of the recovered sandstone artefacts were probably formed in the course of core knapping, oriented at the production of blanks, and - in consequence - tools. Unfortunately, concerning the technological parameters of the rock, we are unable at the moment (as in the case of granite) to determine the purpose of their use.

In light of the cited data, the industries described in this article do not constitute, among of European findings, something unusual, but in Poland they have to be considered as something new. That is why all the observations made must be certainly strengthened through collecting more artefacts and reconstruction, by experimental and technologicalmorphological studies, of the full chaîne opératoire of working the described materials. Confirmation is required also in the case of conclusions drawn in the course of the use-wear 
analyses conducted on the Mesolithic artefacts. Reasons leading to the knapping of the described raw materials remain open. With a high degree of probability it should be stated that reasons should not be sought in the local material situation but rather in cultural traditions.

\section{Notes:}

1. The use-wear analysis has been carried out by Dr Bernadeta Kufel-Diakowska from the Institute of Archaeology at Wrocław University, only for artefacts registered in 2012 (42 pieces). Further analysis is in progress.

2. The rest from the non-flint artefacts identified on the site (154) are different types of grinders, pestles, hammerstones, footings, stone tablets and their fragments with no markers of core exploitation.

3. It is registered usually in primary deposits forming the Rhine terrace (Bolus 1992:9).

4. This bad quality, seldom used, raw material can be found in Rhine gravel deposit (Bolus 1992:9).

5. Is defined as the variant of quartz (detailed definition in Bolus 1992:9-10).

\section{Acknowledgments}

The research at Ludowice 6 was supported by Ministry of Science and Higher Education project No NN109 226140. The research in Lubrza is supported by National Science Centre - project no. DEC-2011/01/D/HS3/04134. We are very grateful to Martin Street for language correction of this article.

\section{References}

Baales, M. 2001, From Lithics to Spatial and Social Organization: Interpreting the Lithic Distribution and Raw Material Composition at the Final Palaeolithic Site of Kettig (Central Rhineland, Germany). Journal of Archaeological Science, 28(2): 127-141. doi: $\underline{10.1006 / j a s c .1999 .0545}$

Ballin, T. B. 2009, Quartz technology in Scottish prehistory. Scottish Archaeological Internet Report (SAIR), 26 (2008), 101 p.

URL: http://archaeologydataservice.ac.uk/archives/view/sair/contents.cfm?vol=26

Bang-Andersen, S. 1996, Coast/Inland Relations in the Mesolithic of Southern Norway. World Archaeology, 27(3) Hunter-Gatherer Land Use: 427-443. doi: $\underline{10.1080 / 00438243.1996 .9980318}$

Bergman, I., Påsse, T., Olofsson, A., Zackrisson, O., Hörnberg, G., Hellberg, E. \& Bohlin, E. 2003, Isostatic land uplift and Mesolithic landscapes: lake-tilting, a key to the discovery of Mesolithic sites in the interior of Northern Sweden. Journal of Archaeological Science, 30: 1451-1458. doi:10.1016/S0305-4403(03)00040-2

Bjartmann Bjerc H. 2008, Norwegian Mesolithic Trends: A Review. In: Mesolithic Europe, (Bailey, G. \& Spikins, P., Eds.), Cambridge University Press, Cambridge: p. 60-106

Bolewski, A., Budkiewicz, M. \& Wyszomirski, P. 1991, Surowce ceramiczne, Wydawnictwa Geologiczne, Warsaw, 397 p. (in Polish) ("Ceramic raw materials")

Bolus M. 1992, Die Siedlungsbefunde des späteiszeitlichen Fundplatzes Niederbieber (Stadt Neuwied), Dr. Rudolf Habelt GmbH, Bonn, 225p. (in German) ("The settlement features of the Late Glacial site Niederbiber, Neuwied city) 
Driscoll, K. \&Warren, G.M. 2007, Dealing with the 'quartz problem' in Irish lithic. Lithics: The Journal of the Lithic Studies Society, 28: 4-14.

Gob, A. \& Jacques, M.-C. 1985, A Late Mesolithic Dwelling Structure at Remouchamps, Belgium. Journal of Field Archaeology, 12(2): 163-175. doi:10.1179/009346985791169481

Hertell, E. \& Tallavaara, M. 2011, High Mobility or Gift Exchange - Early Mesolithic Exotic Chipped Lithics in Southern Finland. In: Mesolithic Interfaces, Variability in Lithic Technologies in Eastern Fennoscandia, (Rankama, T., Ed.), The Archaeological Society of Finland, Saarijärvi: p. 11-41.

Holst, D. 2010, Hazelnut economy of early Holocene hunter-gatherers: a case study from Mesolithic Duvensee, northern Germany. Journal of Archaeological Science, 37: 28712880. doi:10.1016/j.jas.2010.06.028

Kabaciński, J. \& Sobkowiak-Tabaka, I. 2011a, Schyłkowy paleolit i mezolit. In: Osadnictwo pradziejowe $i$ wczesnośredniowieczne w Lubrzy. Ratownicze badania archeologiczne Instytutu Archeologii i Etnologii PAN, Oddział w Poznaniu, T. III, (Kabaciński, J.\& Sobkowiak-Tabaka, I., Eds.), Instytut Archeologii i Etnologii PAN, Poznań: p. 21-28. (in Polish) ("Late Palaeolithic and Mesolithic")

Kabaciński, J. \& Sobkowiak-Tabaka, I. 2011b, Schyłkowy paleolit. In: Materiały do wczesnych pradziejów Zachodniej Wielkopolski. Osadnictwo pradziejowe $i$ wczesnośredniowieczne w Lubrzy. Ratownicze badania archeologiczne Instytutu Archeologii i Etnologii PAN, Oddziat w Poznaniu, T. III, (Kabaciński, J.\& SobkowiakTabaka, I., Eds.), Instytut Archeologii i Etnologii PAN, Poznań: p. 195-262, (in Polish) ("Late Palaeolithic")

Kabaciński, J. \& Sobkowiak-Tabaka, I. 2013, Osadnictwo społeczności kultury hamburskiej na Pojezierzu Lubuskim. Ratownicze Badania Archeologiczne Instytutu Archeologii i Etnologii PAN Ośrodek Studiów Pradziejowych i Średniowiecznych, T. V. Instytut Archeologii i Etnologii PAN, Poznań, 197 p. (in Polish) ("Settlemnt of the Hamburgian culture societies in the Lubuskie Lake District")

Kankaanpää, J. \& Rankama, T. 2011, Spatial Patterns of the Early Mesolithic Sujala Site, Utsjoki, Finnish Lapland. In: Mesolithic Interfaces, Variability in Lithic Technologies in Eastern Fennoscandia, (Rankama, T., Ed.), The Archaeological Society of Finland, Saarijärvi: p. 43-63.

Kind, C. -J. 2006, Transport of lithic raw material in the Mesolithic of southwest Germany. Journal of Anthropological Archaeology, 25: 213-225. doi:10.1016/j.jaa.2005.11.009

Kinkunen, K., Tynni, R., Hokkanen, K \&Taavitsainen, J. P. 1985, Flint raw materials of prehistoric Finland: rock types, surface texture and microfosils. Geological Survey of Finland, Bulletin Vol. 334, Geologian tutkimuskeskus, Espoo, 102 p. Accessed: 09 September 2013. URL: http://arkisto.gtk.fi/bul/bt 334.pdf

Kriiska, A. \& Lõugas, L. 1999, Late Mesolithic and Early Neolithic seasonal settlement AT Köpu, Hiiuma Island, Estonia. In: Environmental and Cultural History of the Eastern Baltic region, (Miller, U., Ed.), PACT Vol. 57, Rixensart, Strasbourg: p. 157-172.

Larsson, L. 1990, The Mesolithic of Southern Scandinavia. Journal of World Prehistory, 4(3): 257-309. doi:10.1007/BF00974882 
Nowakowski, A. 1976, Surowce wulkaniczne Wieliszewa. In: SKAM 71, Zbiór rozpraw prahistorycznych, (Krukowski, S.W. \& Nowakowski, A., Eds.), Zakład Narodowy im. Ossolińskich ,Warsaw: p. 67-75. (in Polish) (Volcanic raw materials of Wieliszew)

Manninen, M. A. \& Knutsson, K. 2011, Northern Inland Oblique Point Sites - a New Look into the Late Mesolithic Oblique Point Traditionin Eastern Fennoscandia. In: Mesolithic Interfaces, Variability in Lithic Technologies in Eastern Fennoscandia, (Rankama, T. Ed.), The Archaeological Society of Finland, Saarijärvi: p. 143-175.

Manninen, M. A. \& Tallavaara, M. 2011, Descent History of Mesolithic Oblique Points in Eastern Fennoscandia - a Technological Comparison Between Two Artefact Populations. In: Mesolithic Interfaces, Variability in Lithic Technologies in Eastern Fennoscandia, (Rankama, T. Ed.), The Archaeological Society of Finland, Saarijärvi: p. 177-211.

Mosin, V.S. \& Nikolsky, V.Y. 2010, Siliceous rock of the southern Urals: Distribution and Osage in the Stone. Archaeology Ethnology \& Anthropology of Eurasia 38(1): 2-9. doi:10.1016/j.aeae.2010.05.001

Mrozek-Wysocka, M. 2013, Analiza petrograficzna i chemiczna przedmiotów ze stanowiska Lubrza 10 (nr inw. L/10/133; l/10/179; l/10/184, Poznań, 9 p. (manuscript) (in Polish) ("Petrographic and chemical analysis of artefacts from site 10 in Lubrza")

Okuniewska-Nowaczyk, I. \& Sobkowiak-Tabaka, I. (in press), Palynological and archaeological studies of the Late Vistulian and Early Holocene at the Lubuskie Lake District (Western Poland). Studia Quaternaria, (in press - 2014).

Olofsson, A. 2003, Pioneer settlement In the Mesolithic of Northern Sweden. Doctor of Philosophy thesis at the Department of Archaeology and Sami Studies, Umeå University, Umeå: 159 p.

Osipowicz, G. (in press), Przemysł ze skał niekrzemiennych w mezolicie ziem polskich? Z wyników badań stanowiska Ludowice 6, gm. Wąbrzeźno, Przegląd Archeologiczny, 61: (in press - 2014). (in Polish) (Industry of non flint rocks in Mesolthic Polish Lands? From the results of the study of the Ludowice 6 site, Wąbrzeźno comm.)

Pallarés, M. \& Mora, R. 1995, Organization strategies of hunter-gatherer communities in the 9th millenium BP along the eastern Pyrenees. In: L'Europe des derniers chasseurs: Épipaléolithique et Mésolithique, $5^{e}$ Collogue international UISPP, Grenoble, 18-23 septembre 1995, (Thévenin, A., Bintz, P., Ed.), Comité des travaux historiques et scientifiques - CTHS, Paris: p. 66-71.

Pelegrin, J. 2000, Les technique de débitage laminaire au Tardiglaciaire critéres de diagnose et quelques reflexions. In: L'Europe centrale et septentrionale au Tardiglaciaire. Actes de la Table-ronde internationale de Nemours, $13-16$ mai 1997, (Bodu, P., Christensen, M. \& Valentin, B., Eds.), Nemour (Mémoires du Musée de Préhistoire d'Ile-de-France Vol. 7), Musée de Préhistoire d'Ile-de-France, Nemours, p. 76-86, (in French) (“Criteria of diagnosis and some reflections on the technique of knapping in the Late Glacial")

Price, T. D. 1991, The Mesolithic of Northern Europe. Annual Review of Anthropology, 20: 211-233. doi:0084-6570/91/1015-0211\$02.00

Přichystal, A. 2002, Zdroje kamenných surovin. In: Paleolit Moravy a Slezka, (Svoboda, J., Czudek, T., Havliček, P., Ložek, V., Macoun, J., Přichystal, A., Svobodová, H. \& Vlček, E., Eds.), Archeologicý ústav AV ČR, Brno: p. 67-76. (in Czech) ("The Palaeolithic of Moravian and Silesia") 
Rankama, T. \& Kankaanpää, J. 2011, First evidence of eastern Preboreal pioneers in arctic Finalnd and Norway. Quartär, 58: 1-27. Accessed: 04 November 2012.

URL: http://www.quartaer.eu/pdfs/2011/2011_rankama.pdf

Sulgostowska, Z. 2005, Kontakty społeczności późnopaleolitycznych i mezolitycznych między Odra, Dźwina a Dnieprem. Studium dystrybucji wytworów ze skał krzemionkowych. Instytut Archeologii i Etnologii PAN, Warsaw, p. 244. (in Polish) ("Contacts between Late Palaeolithic and Mesolithic communities in the area between the Odra, Dvina and Upper Dniester rivers. A study of siliceous artefacts distribution")

Svoboda, J. 2008, The Mesolithic of the Middle Danube and Upper Elbe rivers. In: Mesolithic Europe, (Bailey, G. \& Spikins, P., Eds.), Cambridge University Press, Cambridge: p. 221-237.

Więckowska, H. \& Chmielewska, M. 2007, Materiały do badań osadnictwa mezolitycznego w mikroregionie Luta, województwo lubelskie, Wydawnictwo Instytutu Archeologii i Etnologii PAN, Warsaw, 258 p. (in Polish) (The Mesolithic Settlement in the Luta Microregion, Lublin Voivodeship. Materials) 